\title{
"Plano Pirata" do poema possesso: tempo e humor na poesia brasileira dos anos 1970
}

\author{
"Plano Pirata" of the Possessed Poem: Time and \\ Humor in the Brazilian Poetry of the 1970s
}

Everton de Oliveira Moraes *

\section{Resumo}

$\mathrm{O}$ artigo se propõe a analisar as formas de pensar e lidar com o tempo no "Plano Pirata”, experimento poético publicado pelos poetas Paulo Leminski, Antonio Risério e Régis Bonvicino no final da década de 1970 que fazia uma paródia-homenagem ao "Plano Piloto para Poesia Concreta". Defende-se aqui que o texto traduzia a vivência de uma geração de poetas que apostava no humor como modo do fazer artístico, crítica ético-política e conduta temporal que se configurava como uma das formas pelas quais essa geração participava das disputas pelo tempo naquele momento histórico. Em contraposição ao desejo de atualização e de submissão instrumental do passado às demandas (assumissem elas formas consumistas ou vanguardistas) do presente, tal geração questionava $\mathrm{o}$ atual por meio de uma tensão deste com os múltiplos passados que o habitam, abrindo o agora para suas possibilidades inatuais, desatualizando-o.

Palavras-chave: "Plano Pirata"; tempo; poesia brasileira; Paulo Leminski.

\section{Abstract}

This article proposes to analyze the ways of thinking and dealing with time in the Pirate Plan, poetic experiment published by the Brazilian poets Paulo Leminski, Antonio Risério and Régis Bonvicino in the late 1970s, which made a parody-homage to the "Pilot Plan of Concrete Poetry". It is argued here that the text expresses the experience of a generation of poets that bet on humor as a way of art, of ethicalpolitical critic and temporal conduct that was configured as a way that generation found to participate in disputes over temporality in that historical moment. As opposed to the desire for updating and instrumental submission of the past to the demands (assuming the consumerist or avant-garde forms) of the present, such a generation questioned the actuality by means of a tension of this with the past multiples that inhabit it, opening the now for its possibilities, outdating it.

Keywords: "Plano Pirata"; time; Brazilian poetry; Paulo Leminski.

\footnotetext{
* Universidade Estadual do Paraná (Unespar), Campus União da Vitória, União da Vitória, PR, Brasil. moraes-everton@gmail.com <https://orcid.org/0000-0002-7632-0559>
} 


\section{O “Plano Pirata” do poema possesso}

Em 31 de julho de 1977 foi publicado, no suplemento "Anexo", ${ }^{1}$ caderno de cultura e artes do Diário do Paraná, um experimento poético denominado "Plano Pirata", assinado pelos poetas Paulo Leminski, Antonio Risério e Régis Bonvicino (Leminski; Bonvicino; Risério, 1977). Trata-se de um manifesto-paródia do "Plano Piloto para Poesia Concreta", escrito em 1958 por Haroldo de Campos, Augusto de Campos e Décio Pignatari. O "Plano Pirata" pode ser lido como índice de uma época em que não se produziam mais manifestos (Danto, 2006, p. 33), uma vez que não pretendia ser uma síntese de conceitos que orientassem a produção de um conjunto de artistas, tampouco um documento prescritivo da poética de uma época ou geração. A apresentação ao "Plano Pirata", feita por Leminski, sugeria que o estatuto do texto estava localizado entre o burlesco e o celebrativo, pois pretendia relembrar a importância e a presença do pensamento concreto na sua atualidade e, ao mesmo tempo, tomando certo distanciamento, como é próprio do gesto paródico, apontar para seus limites históricos.

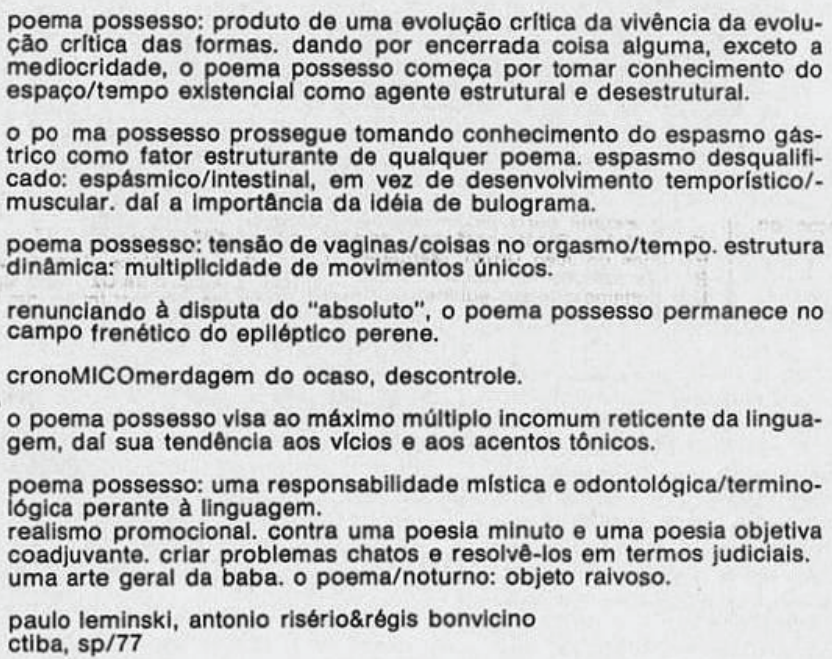
ção critica das formas. dando por encerrada coisa alguma, exceto a mediocridade, o poema possesso começa por tomar conhecimento do espaç/tempo existencial como agente estrutural e desestrutural.

- po ma possesso prossegue tomando conhecimento do espasmo gástrico como fator estruturante de qualquer poema. espasmo desqualificado: espásmico/intestinal, em vez de desenvolvimento temporístico/muscular. dal a importancia da idéla de bulograma.

poema possesso: tensăo de vaginas/coisas no orgasmo/tempo. estrutura dinâmica: multiplicidade de movimentos únicos.

renunciando à disputa do "absoluto", o poema possesso permanece no campo frenético do eplléptico perene.

cronoMiCOmerdagem do ocaso, descontrole.

o poema possesso visa ao máximo múltiplo incomum reticente da linguagem, dal sua tendência aos vicios e aos acentos tónicos.

poema possesso: uma responsabilidade mistica e odontologica/terminológica perante à linguagem.

realismo promocional. contra uma poesia minuto e uma poesia objetiva coadjuvante. criar problemas chatos e resolvê-los em termos judiciais. uma arte geral da baba. o poema/noturno: objeto raivoso.

paulo leminski, antonio risério\&régis bonvicino ctiba, sp/77

Figura 1 - Imagem do "Plano Pirata".

Diário do Paraná, Curitiba, Anexo, 31 jul. 1977.

O "Plano Pirata" foi publicado em um número comum do suplemento, sem grandes destaques, dividindo página com outras experimentações 
poéticas, sem indicações inequívocas de que tenha sido investido de importância maior que qualquer dos outros textos daquela edição. O próprio conteúdo do "Plano Pirata" fornece, aliás, índices de sua ausência de "seriedade", não aparentando ser mais do que uma brincadeira poética composta em meio a uma troca de cartas ou encontro pessoal entre amigos. Mas é precisamente por não se levar muito a sério, por não ter o peso de um manifesto nem possuir caráter prescritivo ou sintetizador, que o poema-paródia expressava algo fundamental a respeito da imaginação da geração da qual os autores faziam parte: o humor - entendido como atitude e como poética -, o deboche, a paródia, a evocação da corporalidade, eram elementos recorrentes não apenas na poesia dos signatários do "Plano Pirata", mas também, em maior ou menor grau, na de vários de seus contemporâneos. Traços que podem ser vistos, para citar outros registros artísticos da época, no cinema dito "marginal" (Coelho, 2010), na produção literária (Cámara, 2014), na música popular (Favaretto, 2000) e nas artes visuais (Freitas, 2013).

Introduzindo o "Plano", Leminski dava o tom do documento: "Este PLANO PIRATA, paródia, é mais que uma paródia do PLANO PILOTO DA POESIA CONCRETA, que, em 1958, deu novos rumos à criação textual brasileira. É o modo de ver sentir de alguns poetas mais jovens que, embora tocados fundo pela passagem da poesia concreta, exigem seus próprios caminhos. Na paródia, a homenagem" (Leminski, 1977c, p. 3).

Homenagem, mas também um modo de se relacionar com a "história das formas". Se o "Plano Pirata" era também, de acordo com Leminski, uma afirmação do desejo de seus signatários de seguir caminhos próprios, tal afirmação confere certa "representatividade" ao documento, que parecia querer sugerir, mesmo que em tom de brincadeira, uma tentativa de marcar, no agora, uma posição em relação a um outrora.

O objetivo deste artigo é, a partir do "Plano Pirata" e de sua tensa relação com o pensamento concreto, pensar as experiências do tempo constitutivas das poéticas de uma determinada geração de artistas (em especial os poetas). Trata-se de um conjunto disperso, que atinge certa maturidade artística a partir do começo dos anos 1970, assumindo, simultaneamente, heranças do tropicalismo e do concretismo, mas também criando para além delas. Esse conjunto de artistas será nomeado aqui, emprestando a expressão de Eduardo Viveiros de Castro (2008), de "tropical-concreto", nome provisório e que não pretende abarcar toda a sua experiência poética, mas que alude ao caráter de "montagem" e de "articulação" que lhes era tão caro, como se pretende demonstrar. Importa lançar luz sobre essa atitude poética que ganhou muitos outros nomes 
(marginal, contracultural, desbunde, pós-tropicalista etc.), sem aderir definitivamente a nenhum, e que apostava no humor como forma de vida e de invenção artística. Interessa, sobretudo, pensar o modo como dois personagens poéticos humorísticos, o "possesso" e o "pirata", traduziam modos de experimentar o tempo que travavam disputas com outras formas de temporalização e buscavam pensar os múltiplos tempos de um Brasil que, ainda sob repressão e censura, começava a vislumbrar a abertura política e a redemocratização. Ao jogar com forças contrárias - o riso do pirata e a paixão do possesso -, a paródia tropical-concreta reproduzia uma das principais características daquilo que Pirandello (2009) chamou de humorismo, isto é, o uso da tensão entre contrários para suscitar uma reflexão crítica.

O tempo, categoria abstrata e complexa, só pode ser apreendido pelo pensamento "através de diversos andamentos, que compõem precisamente uma conduta, como se se passasse de um andamento a outro segundo ocorrências determinadas" (Deleuze, 1991, p. 13). Seria preciso falar, portanto, em "condutas do tempo", isto é, modos de praticar e experimentar o tempo. Para falar com Deleuze, uma conduta do tempo é produto da relação entre "o tempo da história e o pensamento do tempo" (Deleuze, 1991, p. 13). Cada meio ou época implicaria o privilégio a certos ritmos e andamentos (condutas) e a marginalização de outros. Além disso, tais condutas implicariam também experiências da historicidade, isto é, modos de "participação temporal na temporalidade" (Antelo, 2007, p. 56), pelas quais os sujeitos não apenas se situam no interior de determinados "contextos" históricos, agindo "no tempo", mas também participam das disputas "pelo tempo". Importa, portanto, pensar como, a cada momento, passado, presente e futuro são rearticulados para formar um determinado tempo (Araujo, 2012, p. 40), e como esses tempos que, em cada formação histórica, constituem uma multiplicidade, entram em conflito, em fricção, produzindo múltiplas condutas. Dessas, duas nos interessam particularmente: a atualização e a desatualização. A primeira busca tornar o passado e o futuro disponíveis para o uso no presente, por meio de uma apropriação homogeneizante e pré-codificada. É a conduta que se mostra, por exemplo, no gesto revival, tão em voga nas últimas décadas, que consiste em se apropriar de elementos dos passados, recentes ou remotos, para torná-los disponíveis (consumíveis) no presente. Mas que se apresenta também, como se verá neste artigo, no gesto apropriador das vanguardas modernistas e em seu desejo de recolher do passado toda ferramenta que permita acelerar o tempo e fazer o futuro chegar mais rápido. A segunda é a conduta daquele que se reconhece afetado pelas diversas dimensões temporais que atravessam seu "atual" e 
procura fazer dessa afecção um modo de abrir essa atualidade para temporalidades outras (Araujo; Pereira, 2016). É essa que atravessa o modo como o "Plano Pirata" pensa o passado e lhe permite estabelecer uma relação mais complexa com os passados que nele habitam.

O texto parte de uma análise das condutas do tempo mobilizadas pelo "Plano Piloto para Poesia Concreta", objeto da paródia, para depois refletir sobre as relações entre humor, estética e tempo no "Plano Pirata" e, por fim, pensar os modos de pensar e experimentar o tempo implicados na composição dos personagens poéticos denominados "pirata" e "possesso". A partir de pensadores como Deleuze e Pirandello, é possível entender tal vivência como tensão entre contrários que se resolve em um movimento humorístico e crítico, aqui denominado desatualização.

Modos de historicidade: do "Plano Piloto" ao "Plano Pirata"

No Brasil dos anos 1950, o modo desenvolvimentista (que tomava a ideia de desenvolvimento como marco de orientação temporal) de pensar e experimentar o tempo era hegemônico nos meios intelectuais, atravessando não apenas o pensamento político-econômico dominante como parte significativa do pensamento político-cultural. Seja para reivindicar a necessidade de superação do "atraso" brasileiro em nome de um avanço civilizatório e do crescimento econômico, seja para buscar a superação de um estágio de subdesenvolvimento e dependência, econômica ou cultural, em relação aos países ditos desenvolvidos, tratava-se de discursos que adotavam certo tom nacionalista e uma euforia modernizante. O pensamento concretista, que tem no "Plano Piloto" seu documento mais emblemático, foi uma das manifestações desse pensamento desenvolvimentista no espectro artístico.

O "Plano Piloto" já em sua primeira frase afirmava a "evolução crítica das formas" e reivindicava uma "tomada de consciência" da linguagem, em suas dimensões verbal, oral e visual, como agente estrutural da história. Tal evolução era entendida como produto do diálogo crítico constante entre produtores, por meio de inputs e feedbacks, e visava o aumento dessa consciência da linguagem, o conhecimento profundo de seu funcionamento, sua constituição, seus limites e possibilidades. Essa "cronomicrometragem", enquanto processo de controle dos acasos e restos da linguagem, se apresentava como um "realismo total", despojado até mesmo das ilusões comunicacionistas daqueles que pretendiam fazer da poesia, por sua suposta capacidade de expressar emoções, um modo de falar diretamente às massas. É por causa desse alto grau de 
consciência que os autores se permitiam dar "por encerrado o ciclo histórico do verso", assim como de toda tradição que não respondesse adequadamente aos "novos tempos" (Campos; Pignatari; Campos, 1958).

É nessa chave que se deve ler a relação dos poetas concretos com o passado, a divisão que faziam entre aquilo que deveria ser superado - isto é, tudo que não foi selecionado pela "evolução crítica" - e os "precursores" que, tendo sido fundamentais para o movimento de "tomada de consciência", precisavam ser atualizados, relidos a partir do presente. De um lado estavam aqueles elementos que deveriam ser negados e esquecidos: o verso, a comunicação redundante, o pensamento linear e a poesia emocional, entre outros "misticismos" literários (Campos, s. d.); de outro, uma verdadeira "paideuma"2 era evocada como precursora: as experimentações de Mallarmé, Pound, Joyce, Apollinaire, Oswald de Andrade, João Cabral de Melo Neto, Eisenstein, Webern e Boulez, entre outros.

As formas de comunicação e uso criativo da linguagem na poesia concreta deveriam, desse modo, atingir o máximo grau de velocidade e eficiência, funcionando como uma máquina, produzindo doses exatas de comunicação e/ou informação nova. O processo de composição do poema concreto se apresentava como um mecanismo capaz de produzir "objetos industriais racionalmente planejados", "limpos", "reluzentes", de "padrão internacional” (Hollanda, 2004 , p. 46). Nesse aspecto, por mais que seus idealizadores tivessem uma postura política crítica (mais à esquerda do espectro político) e uma sofisticada consciência dos limites e possibilidades de sua linguagem (sem, por exemplo, a "ilusão" de falar às massas populares a partir de um meio erudito - a literatura -, ao contrário da militância artística nacional-popular), o tempo do pensamento concreto estava muito próximo ao tempo desenvolvimentista. Tudo se passa como se o concretismo tivesse elaborado uma forma poética correspondente ao desenvolvimentismo brasileiro do período, que pretendia ser, para a poesia, o que Brasília foi para a arquitetura. Daí o título de seu principal manifesto, que citava o "Plano Piloto" elaborado pelos modernistas Lucio Costa e Oscar Niemeyer.

O horizonte de expectativa do pensamento concreto era o controle racional dos processos de comunicação e produção de informação, de modo a torná-los mais eficientes, isto é, capazes de conjugar ideias e ações em função da realização de determinado objetivo. A constituição do futuro a ser atingido nesse pensamento implicava a substituição do "mágico" e do "mítico" pelo "útil”, um processo ativo e voluntário que selecionava do passado somente aquilo que tivesse a potência para fortalecer o atual e a força para superar tudo 
aquilo que se considerasse como ultrapassado, incapaz de estar "à altura dos novos tempos" (Campos citado em Hollanda, 2004, p. 44). Um passado selecionado e um futuro metrificado eram, desse modo, mobilizados por uma conduta temporal que, além de desenvolvimentista, continha altas doses de atualismo. ${ }^{3}$

Entre os anos finais da década de 1960 e o início da seguinte teve lugar no Brasil a emergência de novas formas de engajamento estético-político, diferentes tanto do "experimentalismo" concreto e neoconcreto quanto da instrumentalização da arte levada a cabo pelos adeptos da estética nacional-popular (segundo a qual a arte deveria ser veículo de difusão de ideias radicais e de constituição de uma nova consciência social). Difundia-se a ideia de que a linguagem artística passava a constituir um dos lugares possíveis de emergência de acontecimentos históricos (Castelo Branco, 2014); a arte poderia "participar" da vida coletiva (política), ainda que modestamente, e não apenas representá-la ou orientá-la de fora. Dessa perspectiva, a dimensão política da arte não deveria estar submetida ao logos, a uma consciência ideal a ser alcançada no futuro, nem servir como instrumento de uma lógica que lhe era exterior, mas sim apostar em suas próprias possibilidades de constituição de sujeitos e acontecimentos políticos.

Muito ligado à Tropicália, esse pensamento não deixava de se reconhecer herdeiro do experimentalismo concreto e neoconcreto, inclusive com muitos de seus representantes (Caetano Veloso, Torquato Neto, Rogério Sganzerla, Jorge Mautner, Paulo Leminski e Waly Salomão, entre outros) mantendo intenso contato com os irmãos Campos e com Décio Pignatari, que a essa altura já haviam transformado muitas de suas posições e modulado seu pensamento racionalista/desenvolvimentista. Parafraseando e subvertendo a definição de Haroldo de Campos, já contaminado pela paixão tropicalista em 1971, seria possível dizer que se tratava de um conjunto de pensadores que buscavam uma experiência existencial como "faiscamento incessante de signos" (Campos, 1971, p. 51). Tratava-se de imaginar políticas da arte que se configurassem como uma aposta na bricolagem existencial e como forma de constituir novos modos de vida. Essa arte, via de regra, não apelava para a ideologia como forma de orientação existencial, mas acreditava na invenção de outras formas de vida (da comunidade hippie às experimentações contraculturais urbanas). Sem ignorar a importância do conhecimento (não se tratava de um irracionalismo), faziam da própria experiência um modo de construí-lo, colocando-a antes da consciência - o corpo antes da alma e a alma como parte do corpo, para falar como Viveiros de Castro (2005) -, ao contrário da política de uma esquerda 
"tradicional" ou "acadêmica", para a qual, em grande medida, a consciência deveria preceder a invenção de uma outra vida. Participaram, portanto, de uma disputa pela imaginação no interior do pensamento político crítico do autoritarismo da Ditadura Militar e de sua modernização conservadora.

Em um momento histórico de declínio das utopias, de crise ecológica e nuclear, de repressão e censura, marcado por uma crescente dificuldade de imaginar futuros radicalmente distintos do presente, esse pensamento abandonou os discursos que diagnosticavam o atraso e afirmavam a necessidade do desenvolvimento e de uma orientação única em direção ao futuro. Tais narrativas afirmavam a busca pela superação das ilusões que impediam o progresso e eram proferidas por aqueles que pretendiam oferecer alguma orientação e sentido e, para tanto, se colocavam como sujeitos (dos concretos aos nacional-populares, passando pelos conceitualistas e artistas de guerrilha) com "maior densidade de consciência em relação à sociedade" (Meireles, 1970). Do ponto de vista da geração tropical-concreta, o discurso do desenvolvimento era uma narrativa de orientação restritiva, que procurava fixar certa ideia de futuro, um horizonte, e, a partir deste, desenvolver apenas as possibilidades já dadas no presente. Interessava, a esse modo outro de fazer arte, inventar oportunidades de transformação, fraturando esse presente e explicitando as múltiplas temporalidades que o constituíam. Não se tratava, entretanto, do tão comentado investimento "pós-moderno" no "aqui e agora”, típico de diversos movimentos contemporâneos, mas de algo como uma aposta em acontecimentos capazes de criar uma indeterminação e uma indefinição na experiência do tempo, confundindo passado, presente e futuro e desatualizando o atual. Era nesse sentido que Risério (1977b, p. 7) afirmava que "num país que vai pra frente, a poesia deve ir para todos os lados".

\section{O HUMOR COMO CONDUTA DESATUALIZADORA}

Se, como já foi dito, era pelo viés do humor, da ausência de solenidade e seriedade que o "Plano Pirata" queria ser lido, caberia perguntar: por que o recurso à paródia para homenagear os "mestres"? O que era esse humor, como ele se apresentava e qual o seu papel naquela poética? Por que o humor pode ser lido como elemento digno de caracterizar certo modo de composição artística e sua relação com o tempo? Qual, em suma, a relação entre arte, humor e temporalidade naquele momento?

Primeiramente, seria preciso falar do humor em seu sentido mais corriqueiro, isto é, como ausência de seriedade, manifestação do burlesco, do 
cômico. Naquele momento, a seriedade e a rigidez pareciam incapazes de sinalizar outra forma de experimentar o tempo para além do clima de "sufoco" produzido pela censura, pela violência e pelo "espetáculo" mobilizado pela modernização conservadora. Para a geração dos signatários do "Plano Pirata", era difícil não associar o "sério" ao "autoritário". Não é à toa que foi exatamente essa geração que, se posicionando à esquerda no espectro político, não poupou críticas ao "patrulhamento ideológico" e à sisudez de um pensamento de esquerda que não conseguia problematizar a si mesmo, reificando o autoritarismo no interior do pensamento crítico do poder. O tropical-concreto apostava no humor, até então visto como menor e desqualificado pelo cânone crítico, como recurso investido de potência crítica e capaz de produzir novas formas de expressão. Era frequente a alusão às qualidades do humor, a afirmação da "perda da fé pelo sério" (Rettamozo, 1977, p. 46), ou a de que "toda coragem é alegre", sendo necessário "cantar", "mesmo sob os realejos desafinados da crítica" (Risério, 1977b, p. 7) e da censura.

Para além do gesto burlesco, a geração tropical-concreta apostava na ideia de humor como atitude poética e conduta do tempo, não necessariamente vinculadas à necessidade de provocar o riso. Ao falar sobre o cartum, mas generalizando para o humor, Leminski argumentava:

O mais importante sobre o humor é que ele não é uma arte. É uma arte das artes. Um diálogo entre códigos. É na intersecção entre o código verbal das palavras e um código plástico como o desenho que se dá o humor. [...] Humor é uma palavra ruim. Dá a impressão que é pra dar risada. Não é nada disso. É outra coisa. É poesia. Com palavras. Ou sem palavras. Os maiores poetas foram humoristas. Não há poesia sem humor. Todo humor é poesia. [...] Os maiores talentos poéticos desta geração desertaram e foram para a música popular ou para o cartum. Os que liam (líamos) gibi, agora, fazem. [...] E agora a grande geração de cartunistas. Cada vez mais numerosos. Cada vez mais hábeis. Cada vez mais fortes. Onde estão os poetas? Certamente não mais naquele lugar que se chamava até ontem de poesia. O humor é uma das grandes saídas desta geração do impasse da cultura letrada face ao mundo industrial e dos grandes meios de massa, que são icônicos e intersemióticos. [...] Os poetas estão imigrando para outros códigos. (Leminski, 1977d, p. 12)

O impasse ao qual Leminski alude, a tensão entre a "cultura letrada" e os "meios de massa", foi vivido com dramaticidade por artistas e intelectuais brasileiros desde, pelo menos, a década de 1930, sendo aprofundado pela 
modernização conservadora e o consequente crescimento da mídia de massas, especialmente a televisão. Como o poeta comenta em diversos ensaios, esse impasse não deveria ser resolvido por meio de uma domesticação dos meios de massa - icônicos e intersemióticos - pela cultura letrada (resposta nacional-popular), nem por um investimento definitivo e sem reservas no intersemiótico (resposta concretista). E se o humor era entendido por Leminski como saída para esse impasse, é porque ele implicaria uma capacidade de deslocamento, de trânsito e de tensão entre diferentes códigos e meios, um jogo constante entre distanciamento e aproximação. Essa "arte das artes", tão presente nos cartuns e na música popular da época, permitiria colocar em estado de suspensão o uso que se fazia da linguagem poética, possibilitando hibridações criativas. Leminski falava ainda do humor como "código devorando código" (Leminski citado em Rettamozo, 1977, p. 7), possibilidade de o artista transitar entre o dentro e o fora, fazendo uma constante crítica de si mesmo. Daí que, assim como ele, boa parte da geração tropical-concreta pensasse a sua relação com os "meios de massa" como um jogo marcado pela tensão, com diversos tipos de intervenções e trocas possíveis.

Leminski parecia ecoar as palavras de Pirandello (2009) quando este afirmava que o humor era uma forma muito específica de arte, uma vez que, ao lidar com a tensão entre contrários, permitiria não apenas questionar as ficções humanas em geral (os valores), mas também fazer o artista e o receptor problematizarem o modo mesmo pelo qual criam nesta ou naquela ficção, abrindo a possibilidade para outras formas de organização da existência e do tempo. No caso do texto aqui analisado, tratava-se, em um primeiro momento, de convocar pela paródia o riso típico daquele que se distancia do objeto parodiado (gesto apropriador do "pirata"), mas sem deixar de evocar, ao mesmo tempo e de modo mais sutil, uma reflexão sobre a relevância histórica e, para além dela, a presença fundamental do poema concreto na atualidade e em seu modo de fazer arte (possessão). Daí que, na sua introdução ao "Plano Pirata", Leminski alerte que se trata ali não apenas de paródia, mas também de homenagem ao grupo que "deu novos rumos à criação textual brasileira". Essa tensão humorística não resolvida teria como efeito a produção de uma hibridização entre duas formas de lidar com a tradição do pensamento artístico brasileiro: o distanciamento crítico, que aponta para uma apropriação seletiva, um "uso" do passado, e a paixão, que possibilita o reconhecimento da presença de temporalidades pretéritas no interior do tecido aparentemente liso do presente.

Para precisar um pouco melhor o que se entende aqui por humor e qual seria sua relação com a temporalidade, caberia evocar o sentido que Deleuze 
dá ao conceito, distinguindo-o da ironia. A atitude irônica seria caracterizada por uma crítica produzida de um ponto de vista distanciado e superior, com seu pretenso universalismo, fortalecendo a posição do sujeito que enuncia a crítica. O humor, diferentemente, funcionaria fazendo gaguejar a língua do humorista, jogando-a em um devir-minoritário, contestando-a em sua própria imanência, em um gesto autoderrisório. Interpretando o "Plano Pirata" a partir dessa ideia de humor, seria possível dizer que ele pretendia fazer a poesia "fugir" da Literatura enquanto forma institucionalizada do acontecimento poético e possibilitar ao poema acontecer em outras formas de expressão, como o cartum ou a música popular. Se a ironia do "Plano Piloto" estaria ligada a uma teleologia desenvolvimentista, a uma superação do passado em direção a um futuro idealizado, o tempo humorístico do "Plano Pirata" era o tempo do agora, da tensão entre temporalidades capaz de se desatualizar pelo contato com outros tempos. Sem nenhum conteúdo a ser defendido ou reivindicado (um modo específico de fazer poesia, por exemplo), o "Plano Pirata" se admitia afetado pelo concretismo, ao mesmo tempo que o fazia gaguejar pela fricção com a alegria e a derrisão tropicalista, mantendo ambas as poéticas em estado de tensão (Deleuze; Parnet, 1998, p. 56). Assim, o seu atual, mais do que um ponto específico em uma linha cronológica, aparecia como um átimo de indeterminação temporal. O "Plano Piloto" era, desse modo, trabalhado a partir de movimentos de aproximação e distanciamento, sendo objeto não de uma atualização, mas de uma desatualização, que permitiria uma rearticulação das formas daquela experiência do tempo.

Ao relacionar paródia e autorreflexividade, essa capacidade de atentar para a contingência de seu próprio modo de pensamento, a análise de Linda Hutcheon privilegia o gesto que se apropria e recontextualiza aquilo que parodia a partir de uma vontade atualizadora, mais do que o modo como o "objeto" parodiado afeta esse gesto do sujeito da paródia (Hutcheon, 1989, p. 49). O que se defende neste artigo é que o "Plano Pirata" (assim como obras de outros artistas daquela geração) chama a atenção também para o afeto do "objeto" da paródia sobre o gesto do sujeito que parodia. Desse modo, a paródia humorística permitia que as poéticas mobilizadas pela geração do "Plano Pirata" se mantivessem constantemente tensionadas entre o gesto que "re-utiliza" o passado (aquele do "pirata" que dá título ao "Plano") e um outro que sofre a paixão do tempo (a conduta do poeta "possesso"). Essa tensão, presente não apenas ali, era constitutiva daquela geração. Caberia agora analisar precisamente essas duas figuras da imaginação poética daquele momento. 


\section{O PIRATA}

O que significava, naquele momento e para aqueles poetas, definir sua poesia como pirata? A imagem do pirata, nas suas mais diversas acepções, remete à figura do sujeito que rouba, saqueia, que se apropria do que não é seu. Desse modo, esse personagem poético-conceitual poderia ser comparado a outro, que vinha sendo recuperado precisamente naquele momento por diversos adeptos do tropical-concreto: o "antropófago". Essa figura, imaginada por Oswald de Andrade na década de 1920, suscitava cada vez mais interesse entre os artistas experimentais. Interesse que levou também à republicação dos dez volumes da Revista de Antropofagia em 1977. Apenas algumas semanas antes de publicar o "Plano Pirata" no suplemento "Anexo", Leminski apresentava, no mesmo caderno, o "Manifesto Antropófago"; meses mais tarde, publicaria ali um artigo intitulado "Está de volta o gosto pela carne humana", no qual chamava a atenção para esse retorno inesperado da antropofagia oswaldiana (Leminski, 1977b, p. 5). Nesse mesmo ano, Risério (1977a, p. 3) e Bonvicino (1977, p. 5) abordariam, em ensaios publicados no "Anexo", a importância do gesto antropofágico na arte brasileira.

Outra amostra dessa recuperação é o poema "Interessere", de Décio Pignatari, de 1976, que fazia o elogio de uma ontologia da devoração, ecoando um dos motes do "Manifesto Antropófago" de 1928: "só me interessa o que não é meu”, que bem poderia ser considerado uma frase própria de piratas. Por meio dele, tanto Oswald como seu "devorador", Pignatari, afirmavam uma postura radical de defesa da "posse contra a propriedade", uma ética da apropriação que muito se aproxima do "saque" à tradição efetuado pelo "trapeiro" de Benjamin. Era esse saque ao passado que abria a possibilidade da reutilização e da rearticulação paródicas. A pirataria, desse modo, estava marcada pelo gesto consciente de se apossar de outras culturas e historicidades e degluti-las, recolhendo delas o que interessava e dando-lhes outro tempo, outro futuro. Tratar-se-ia, nesse caso, de um gesto ativo e voluntário e não de mera reação. No caso, como Leminski dizia na introdução do "Plano Pirata", estava em questão construir os próprios caminhos, afirmar suas especificidades em relação aos seus antecessores concretos.

As cartas de Leminski para Bonvicino, publicadas posteriormente em livro, permitem um acesso privilegiado a essa tentativa. Nelas, o poeta curitibano afirmou diversas vezes a necessidade de não se limitar aos rigores concretistas; apesar de reconhecê-los como fundamentais para a constituição da poética de sua geração (muitas vezes acusada de ser mera continuadora do 
formalismo concreto), considerava que deveriam ser retrabalhados, reconfigurados e combinados com a "paixão" tropicalista para produzir outra coisa ainda sem nome e que Leminski apenas esboçara chamar, em alguns ensaios, de "post-literatura".

A pirataria implicaria, nessa concepção, outra forma de "posse contra a propriedade" ou, para ficar na terminologia leminskiana, uma "propriedade coletiva dos bens de invenção” (Leminski, 1992, p. 77). Um modo de relação com a autoria e com a propriedade radicalmente distinto dos modos hegemônicos em seu momento histórico, isto é: a censura, que precisava atribuir a obra a um autor (responsável pela propriedade intelectual), um vetor a quem culpabilizar pela disseminação do vírus da subversão e da desobediência (Nodari, 2012, p. 163); e a sociedade de consumo, caracterizada por uma autoria e uma propriedade mais fluidas, dispersas, mas sobrecodificadas pelos signos da mercadoria.

A paródia é a forma por excelência desse gesto de apropriação, já que pressupõe um objeto-signo do qual se apossa, bem como sua rearticulação a partir de outro contexto. O "Plano Pirata", nesse sentido, funcionava como uma espécie de crítica (em voga entre os poetas contraculturais) de um modo de fazer poesia que havia marcado a história da literatura brasileira, mas também como homenagem, já que era constitutivo do pensamento poético de gerações de poetas experimentais. Ao parodiar, era possível marcar tanto sua reverência como sua diferença em relação aos "mestres", afirmando, por meio do humor, um modo de lidar com o tempo. Essa mesma atitude paródica, no entanto, impedia que essa tomada de posição pudesse ser encarada como uma ruptura completa, já que na paródia também se bloqueava a possibilidade dos "gestos inaugurais" característicos dos manifestos modernistas (dos quais o "Plano Piloto" foi um dos últimos). Daí que Leminski afirmasse, em outra carta a Bonvicino, que eram eles (sua geração) “os últimos concretistas e os primeiros não sei o que lá", nesses tempos em que "as certezas se evaporam" (Leminski, 1992, p. 44).

A paródia era entendida como uma poética precisa e sugestiva para esses tempos de incertezas. Mas quais eram os procedimentos que o "Plano Pirata" mobilizava para parodiar o "Plano Piloto"? E qual a diferença produzida por essa poética? O "Plano Pirata" não apenas mantinha a estrutura de manifesto do "Plano Piloto" como reproduzia suas frases com a substituição de algumas palavras-chave. Tais substituições é que tornavam burlesco o texto-paródia e permitiam que seus signatários tomassem certa distância do "original”, marcando assim sua posição, sua diferença. À aura de seriedade e rigidez que os concretos atribuíam a sua tarefa histórica (interferir na arte em nível mundial, aumentar a consciência de um "povo", fazer do Brasil um polo exportador de 
poesia e experimentação artística), os piratas opunham o ridículo e o escatológico, por meio da simples troca de algumas palavras.

Se a poesia concreta se afirmava como o "produto de uma evolução crítica de formas dando por encerrado o ciclo histórico do verso", o poema possesso, por sua vez, não encerrava "coisa alguma", não começava nada, não pretendia refundar a estética. Ao se colocar como um "produto de uma evolução crítica da vivência da evolução crítica das formas” ele parecia afirmar um grau a mais de consciência e autocrítica em relação à "evolução crítica" concreta. Impressão apenas parcialmente verdadeira e contestada por pelo menos dois elementos: a introdução do termo "vivência", que remete à ideia de uma experiência propriamente dita desse projeto, colocada agora como um parâmetro tão ou mais significativo para a avaliação histórica e crítica; e a frase segundo a qual o "Plano Pirata" começava "dando por encerrada coisa alguma”, que afirmava que já não se tratava mais de destruir os monumentos do passado, mas justamente de historicizá-los ("tomar conhecimento do espaço/tempo existencial como agente estrutural e desestrutural”) para reutilizá-los (Nodari, 2015, p. 69).

No "Plano Piloto" apareciam construções como "poesia concreta: tensão de palavras-coisas no espaço-tempo. estrutura dinâmica: multiplicidade de movimentos concomitantes" e "a poesia concreta visa ao mínimo múltiplo comum da linguagem", que deixavam clara a projetualidade, os diversificados focos de atuação e a precisão de seus objetivos, delineando uma teleologia racionalista. Tratava-se, no "Plano Pirata", de criar uma "estrutura dinâmica: multiplicidade de movimentos únicos”, isto é, a produção de uma multiplicidade de acontecimentos singulares, estranhos, que se articulariam muito mais por contágio e sintonia do que por obra de um projeto que os codificasse e delimitasse sua posição. Em vez do tom de certeza do texto concretista, afirmava o "máximo múltiplo incomum reticente", que admitia a incerteza e não buscava restringir a multiplicidade dos futuros por meio de um "controle", uma "cronomicrometragem do acaso", reduzindo-os a um ideal de desenvolvimento. Em relação a esses procedimentos, os piratas ofereciam uma "cronomiCOmerdagem do ocaso", "descontrole", permanecendo sem rumos definidos, "no campo frenético do epilético perene".

Caberia, ainda, citar os trechos finais dos dois "Planos" como forma de atentar para o modo como descreviam o objeto poético na sua relação com as realidades que o atravessam. No "Plano Piloto" podemos ler a seguinte definição: "poesia concreta: uma responsabilidade integral perante a linguagem. realismo total. contra uma poesia de expressão, subjetiva e hedonística. criar problemas 
exatos e resolvê-los em termos de linguagem sensível. uma arte geral da palavra. o poema-produto: objeto útil" (Campos; Pignatari; Campos, 1958).

No "Pirata", por sua vez, esses trechos finais tornavam ainda mais explícito o caráter burlesco do texto: "poema possesso: uma responsabilidade mística e odontológica/terminológica perante a linguagem. realismo promocional. [OBJETIVO]: criar problemas chatos e resolvê-los em termos judiciais. uma arte geral da baba. o poema/noturno: objeto raivoso" (Leminski; Bonvicino; Risério, 1977, p. 3).

Se no primeiro tratava-se de produzir um "objeto útil”, pronto para o uso, mediante trabalho sobre a linguagem sensível da arte, no segundo importava inventar um "objeto raivoso", sobre o qual não se pretendia ter controle, sem um "fim" previamente definido, produto tanto do desejo apropriador como de um corpo possuído pelos afetos que o atravessavam e desatualizavam. Mesmo essa conduta apossadora era, portanto, derivada de uma experiência das afecções do tempo. Tal experiência é produto de uma releitura da antropofagia que vinha sendo efetuada desde as experimentações de Hélio Oiticica e da Tropicália, e que agora aparecia encarnada no personagem conceitual denominado "possesso". É sobre ele que interessa agora pensar.

\section{O POSSESSO}

O uso do termo "possesso" para designar a forma do poema descrito pelo "Plano Pirata" tem pelo menos dois significados: à primeira vista, trata-se de uma paródia do "poema processo", vanguarda poética que defendia a formalidade iconográfica do poema; entretanto, analisando com mais profundidade, o conteúdo do "Plano" sugeria que tal uso dizia respeito, talvez, a um signo importante naquele momento, e indica que ele poderia ser tomado como uma das possíveis chaves de leitura do texto. Mas qual o significado desse termo? Quem se diz possesso, se diz despossuído de si, possuído por outrem, espírito ou força, tomado por uma paixão, um pathos. ${ }^{4} \mathrm{~A}$ ideia de possessão, de um "poema possesso", pode ser relacionada ao modo como os afetos da realidade imediata atingiam os corpos, produzindo uma afecção semelhante a um "ser tocado de dentro" (Gumbrecht, 2013, p. 13), fazendo o sujeito ser tomado por forças que o atravessam, perdendo o controle de si mesmo. O poeta possesso, desse modo, era aquele que havia abandonado o desejo por "gestos inaugurais" e que não postulava a última palavra em termos de poesia, aquela que viria para substituir todas as outras, já superadas. Tudo se passava, para esses poetas, como se de repente fossem possuídos por certos poetas do passado, que neles 
encarnariam, tornando possível, para os primeiros, respirar "o mesmo ar que respiravam" os segundos, uma espécie de sintonia anacrônica. Nessa possessão, em que a alma dos mortos se reanimava através dos corpos dos vivos, os seres (poetas) deixavam de ter uma identidade bem definida, a alma deixava de ter relação com um corpo específico e tornava-se possível se sintonizar com o "clima" de outro tempo. A "metafísica do ser", isto é, dos seres uns ao lado de outros, habitando um único mundo, era confrontada por uma metafísica do "haver", em que, ao invés de sujeitos constituídos, havia quase-sujeitos, sempre inacabados, abertos, reconstituindo-se e se recompondo por meio de possessões que os assaltavam (Viveiros de Castro, 2005, p. 11). Assim, o corpo assumia papel fundamental para o "Plano Pirata".

O corpo é um agregado de órgãos, peles, carnes, líquidos, membranas e, no limite, bactérias, moléculas e átomos, conectados por uma complexa rede de ligações e estímulos energéticos. É o pensamento que, postulando sua autonomia relativa em relação ao corpo que habita, permite unificá-lo e tomá-lo como um todo, portador de uma natureza e de uma identidade, ligado a um só “espírito". O corpo possesso, entretanto, é dividido: um espírito outro o invade e assume o controle, deixando a alma original em suspenso, em estado de sono. É esse caráter dividual que constitui, portanto, a característica principal do corpo possuído. Mais almas o habitam e provocam confusão, uma nova organização, uma remontagem. É, em suma, o corpo em sua fragmentariedade que é revelado pela possessão. São bem conhecidas, nesse sentido, as performances de artistas da época que, tomados pela sua obra, pareciam ter seus corpos possuídos por entidades durante seus happenings, inclusive aqueles que, como Waly Salomão, faziam de todos os momentos de exposição pública um evento de possessão, como se quisessem tornar a própria existência um happening incessante.

Falar em "poema-possesso", nesse sentido, para além da paródia, equivaleria a pensar a poesia como "corpo que vira qorpo" (Bonvicino, 1977, p. 5), isto é, não unificado, mas cindido, dividido, possuído por outros poemas e outras forças. Daí que boa parte da produção do grupo tropical-concreto recorresse ao método da montagem, pois ele seria capaz de dar conta de uma desorganização e fragmentação que havia se colocado como problema para os poetas. A uma possessão do corpo poético responderia uma montagem do texto/poema/objeto, não como forma de tentar reunificar o corpo fragmentado da arte, mas de extrair dessa fragmentação suas consequências mais radicais.

Considerando que escrever é um ato indissociável da capacidade de ser afetado (possuído), era possível para Leminski, Risério e Bonvicino pensar os 
textos ou poemas como corpos. Afirmando a corporeidade do poema, os signatários do "Plano Pirata" não apontavam para a escrita como uma prática e constituição de algum tipo de coesão orgânica, o que implicaria a construção de sentidos mediante explicação e argumentação, como no paradigma logocêntrico. Antes, sua escrita fragmentária e evocativa era a tentativa de criar imagens, montagens e analogias, estas entendidas como produtos e produtoras de afecções. Essas narrativas em verso possuíam uma abertura que a narrativa prosaica, com sua vontade de explicação e de fechamento, não tinha. Não se tratava, entretanto, de uma escrita menos densa, mas de uma tentativa de produzir mais efeitos com menos recursos verbais, sem desperdício nem consumismo. Sem o fetiche das palavras. "Artilharia ligeira" lançada contra o humanismo logocêntrico (Rebuzzi, 2003, p. 67). Nas palavras de Leminski (1977d, p. 6): "minha luta sempre foi intersemiótica, isto é, pelos direitos dos outros códigos e pela necessidade de uma interação/atrito entre todos, inclusive o verbal". Essa escrita intersemiótica possibilitava a dessubjetivação, a desmontagem do sujeito soberano e o "destronamento" do "código verbal" no qual se sustentava.

Diferentemente da poesia concreta, controlada e racional, "o poema possesso prossegue tomando conhecimento do espasmo gástrico como fator estruturante de qualquer poema", trabalhando a partir dos estados do corpo, dos incômodos intestinais, daquela diarreia e daquela prisão de ventre comentadas por Oiticica (1982), referência importante para os compositores do "Plano Pirata". Todo poema era o resultado contingente das deglutições e dos efeitos destas no corpo, mas ele mesmo (o poema) também se constituía como corpo antropófago, que se alimentava de outros poemas-corpos, mas que também os alimentava, dando-lhes sobrevida.

O caráter atualista e desenvolvimentista das posturas artísticas concretas e de outros movimentos de vanguarda era questionado: o "espásmico/intestinal desqualificado" em vez do "desenvolvimento temporístico linear”. Antes dos músculos, instrumentos da vontade que constrói e destrói soberanamente, tornava-se importante deslocar a atenção para o intestino, que recebe e processa tudo aquilo que é deglutido. A ênfase, portanto, passava da ação ("palavras/coisas" atuando sobre um "espaço/tempo", no "Plano Piloto") para a paixão, para a "tensão entre vaginas/coisas no orgasmo/tempo". A vagina aparece como abertura, como metáfora de outra forma de se relacionar com o tempo, em vez do falo, símbolo do ativismo e do autonomismo moderno.

Para essa arte, certa ideia de paixão era fundamental. Tal conceito seria abordado com profundidade por Leminski somente em 1986, em momento 
posterior ao recorte temporal deste texto (Leminski, 1986). No entanto, defende-se aqui que essa ideia de paixão já estava presente na poesia de sua geração. Mas o que é, afinal, a paixão? No texto citado, Leminski definiu a paixão como uma espécie de sofrimento ativo, capaz de provocar mudanças nos sujeitos (Leminski, 2009, p. 325-326). Tratava-se de um sofrimento ligado não à ideia de dor, mas à condição de ser passivo de uma ação, de ser objeto de um afeto, de uma força. Ser afetado, sofrer, ser passivo, nesse sentido, poderia ser uma forma de atividade, de invenção. Ser passivo de um afeto equivaleria a passar por um acontecimento dessubjetivador, em que uma força provocaria a desestabilização do sujeito, que perderia a certeza de ser quem era. Para Leminski, o poeta era justamente aquele que sofria constantemente a força da língua, um "sofredor da língua”, encontrando incessantemente seus afetos e se mantendo sempre aberto a eles, buscando cartografar suas regularidades e incorporar os erros, as errâncias, as fugas dessa língua, nunca se fechando em identidades e normatividades preexistentes. O poeta, o criador, era aquele que sabia se manter em certa quietude, para melhor acolher os afetos (Leite, 2012, p. 100-102), mas que, no momento oportuno, "passa a devolver os golpes que tinha sofrido no início, no qual era uma vítima da língua, [...] passa a ser algoz, [...] torturá-la, a quebrá-la, passa prum outro momento de sua paixão" (Leminski, 1986, p. 327).

Parte-se, desse modo, para uma leitura da antropofagia que colocava o acento não apenas na devoração do outro e na incorporação de suas intensidades, mas que retomava um aspecto já presente na antropofagia oswaldiana, porém pouco lembrado, a saber, o afeto que o devorado exercia sobre o devorador (Nodari, 2015, p. 40-41). A relação dos signatários do "Plano Pirata" com a alteridade temporal não era, portanto, orientada somente para a atualização e para o uso, como no caso do concretismo, como poderia parecer quando se leva em conta apenas o "pirata" do título. A passividade e a possessão envolviam, é certo, um uso do passado e do futuro, mas este não dizia respeito a uma manipulação mobilizada por um sujeito soberano, seguro de si. Somente na medida em que se era "usado" por outras temporalidades, afetado por elas, era possível praticar uma forma de uso capaz de abrir sua atualidade para outros tempos, desatualizando-a.

\section{CONSIDERAÇÕES FINAIS}

O humor, enquanto suspensão da figura atual do Eu, funcionava também como suspensão de sua atual conduta do tempo, como abertura do sujeito para outras articulações. Não era outra coisa que Leminski afirmava quando 
defendia uma articulação da poesia com a música popular e com o cartum ou quando transportava Descartes para o Brasil, onde sua filosofia europeia se perde em meio à multiplicidade caótica da floresta (Leminski, 2010). Era essa mesma potência de rearticulação que Risério tinha em mente quando, respondendo sobre um possível modo de enfrentar o problema da colonização imperialista da cultura do país, defendia, de forma aparentemente paradoxal, que a melhor saída consistiria em apropriar-se do que de mais sofisticado havia nas culturas estrangeiras. Tal resposta apontava não para a necessidade de desenvolvimento e de equiparação do Brasil com os países desenvolvidos, mas para aquele desejo antropofágico que se interessa por tudo aquilo que não é seu, que não é idêntico a si mesmo. Essa apropriação da cultura estrangeira deveria ser combinada com a recuperação do mais arcaico, a saber, a vividez do "vermelho" que cobria o corpo dos ameríndios avistados por Caminha e que "foi submetido à ação sistemática de detergentes tecnológicos europeus" (Risério citado em Leminski, 1977a, p. 2). Não se tratava, portanto, nem da busca de uma cultura autenticamente nacional (desenvolvimentismo nacional-popular), nem da mera internacionalização da cultura brasileira (atualismo globalizante).

Se Risério afirmava que o "brasileiro é uma fantasia", isto é, uma articulação, e que uma coisa era "ser brasileiro quando Hans Staden escrevia [...] e outra, bem distinta, [...] quando Getúlio Vargas se suicidava” (Risério citado em Leminski, 1977a, p. 2), é possível derivar dessa afirmação que o próprio Brasil é também uma fantasia (uma abstração, para falar como Leminski) que se transforma historicamente e cujo sentido pode ser disputado. Em um momento no qual se começava a vislumbrar a abertura política e a debater um virtual futuro democrático, isso significava que era possível e desejável imaginar formas outras de habitar o Brasil, o que representava a necessidade de rearticular os territórios existenciais e as temporalidades.

O "Plano Pirata" rearticulava a "informação" concreta e a "paixão" tropicalista para dar consistência aos personagens poéticos que nomeava como pirata e possesso e que representavam afetos contrários, próprios do gesto humorístico e de sua conduta temporal desatualizadora. A “invenção" tão reivindicada pelos tropical-concretos partia da ideia, tipicamente concretista, do passado como "repertório estocástico", mas assimilava dos tropicalistas a relação com o passado como afeto, irrupção do arcaico, corte que perturba o presente. Essa invenção é, portanto, o gesto capaz de rearticular os tempos pretéritos para imaginar um futuro distinto da atualidade. 
As políticas do tempo mobilizadas por piratas e possessos evocavam o humor da antropofagia oswaldiana, mas o faziam por meio de uma releitura que acentuava não apenas a sua dimensão devoradora e apropriadora, mas também a ideia de que o devorado afetava e transformava o devorador desde dentro. Tendo esse humor como fundamento, a arte deixava de ser o modelo de eficiência para as demais esferas sociais ou "a metáfora máxima da superação da divisão social do trabalho" (Freitas, 2013, p. 322), sem, contudo, tornar-se mera celebração do atual por meio do consumo. Diferente da ironia desenvolvimentista ou revolucionária, o humor tropical-concreto pensava o artista como figura que possui uma posição bem delimitada no circuito dos afetos e das ocupações e que age "modestamente", sem nenhuma pretensão prometeica. Mais do que construir novas formas ou superar modos de lidar com a arte, seu papel, nessa perspectiva, seria o de se conectar com as forças de desatualização e fazê-las crescer.

\section{REFERENNCIAS}

ANTELO, Raúl. Tempos de Babel: destruição e anacronismo. São Paulo: Lumme, 2007. ARAUJO, Valdei. A história da historiografia como analítica da historicidade. História da Historiografia, Ouro Preto: Ufop, v. 12, p. 34-44, 2012.

ARAUJO, Valdei; PEREIRA, Matheus H. F. Reconfigurações do tempo histórico: presentismo, atualismo e solidão na modernidade digital. Revista UFMG, Belo Horizonte, v. 23, n. 2, p. 270-297, jan./dez. 2016.

BONVICINO, Régis. Ecologia da poesia. Diário do Paraná, Curitiba, Anexo, 9 jul. 1977.

CÁMARA, Mario. Corpos pagãos: usos e figurações na cultura brasileira (1960-1980). Belo Horizonte: Ed. UFMG, 2014.

CAMPOS, Augusto de; PIGNATARI, Décio; CAMPOS, Haroldo de. Plano-Piloto para Poesia Concreta. Noigandres, São Paulo, v. 4, 1958. Disponível em: http://tropicalia. com.br/leituras-complementares/plano-piloto-para-poesia-concreta. Acesso em: 15 fev. 2018.

CAMPOS, Haroldo de. Vanguarda. Revista Tempo Brasileiro, Rio de Janeiro, n. 26-27, jan./mar. 1971.

CAMPOS, Haroldo de. Olho por olho a olho nu. Poesia Concreta: o projeto verbivocovisual. S. d. Disponível em: http://www.poesiaconcreta.com.br/texto_view. php?id=7. Acesso em: 13 dez. 2015. 
CASTELO BRANCO, Edwar de Alencar. PO-EX: a poética como acontecimento sob a noite que o fascismo salazarista impôs a Portugal. Revista Brasileira de História, São Paulo: Anpuh, v. 34, n. 67, p. 131-155, jan./jun. 2014.

COELHO, Frederico. Eu, brasileiro, confesso minha culpa e meu pecado: cultura marginal no Brasil das décadas de 1960 e 1970. Rio de Janeiro: Civilização Brasileira, 2010.

DANTO, Arthur. Após o fim da arte: a arte contemporânea e os limites da história. São Paulo: Odysseus: Edusp, 2006.

DELEUZE, Gilles. Prefácio. In: ALLIEZ, Eric. Tempos capitais. São Paulo: Siciliano, 1991.

DELEUZE, Gilles; PARNET, Claire. Diálogos. São Paulo: Escuta, 1998.

FAVARETTO, Celso. Tropicália: alegoria alegria. São Paulo: Ateliê, 2000.

FREITAS, Artur. Arte de Guerrilha: vanguarda e conceitualismo no Brasil. São Paulo: Edusp, 2013.

GUMBRECHT, Hans Ulrich. Atmosfera, ambiência, Stimmung. Rio de Janeiro: Contraponto, 2013.

HOLLANDA, Heloísa Buarque de. Impressões de viagem: CPC, vanguarda e desbunde: 1960/70. Rio de Janeiro: Aeroplano, 2004.

HUTCHEON, Linda. Uma teoria da paródia. Lisboa: Ed. 70, 1989.

LEITE, Elizabeth Rocha. Leminski: poeta da diferença. São Paulo: Edusp, 2012.

LEMINSKI, Paulo. Antonio Risério: Rumo à cidade do sol. Entrevista de Antonio Risério a Paulo Leminski. Diário do Paraná, Curitiba, Anexo, 29 maio 1977a.

LEMINSKI, Paulo. Uma carta uma brasa através: cartas a Régis Bonvicino (1976-1981). São Paulo: Iluminuras, 1992.

LEMINSKI, Paulo. Catatau: um romance-ideia. São Paulo: Iluminuras, 2010.

LEMINSKI, Paulo. Está voltando o gosto pela carne humana. Diário do Paraná, Curitiba, Anexo, 8 jul. 1977b.

LEMINSKI, Paulo. “Este Plano Pirata...”. Diário do Paraná, Curitiba, Anexo, 31 jul. 1977 c.

LEMINSKI, Paulo. Humor: esse duélago. Diário do Paraná, Curitiba, Anexo, 12 jul. 1977d.

LEMINSKI, Paulo. Poesia: paixão da linguagem. In: NOVAES, Adauto (org.). Os sentidos da paixão. São Paulo: Companhia das Letras, 2009.

LEMINSKI, Paulo; BONVICINO, Régis; RISÉRIO, Antonio. Plano Pirata. Diário do Paraná, Curitiba, Anexo, 31 jul. 1977.

MEIRELES, Cildo. Inserções em circuitos ideológicos. 1970. Disponível em: http:// passantes.redezero.org/reportagens/cildo/inserc.htm. Acesso em: 10 jan. 2016.

NODARI, Alexandre. Censura: ensaio sobre a "servidão imaginária”. 2012. Tese (Doutorado em Literatura) - Programa de Pós-Graduação em Literatura, UFSC. Florianópolis, 2012. 
NODARI, Alexandre. “A transformação do Tabu em totem”: notas sobre (um)a fórmula antropofágica. dasQuestões, n. 2, fev./maio 2015.

PIRANDELLO, Luigi. O humorismo. In: GUINSBURG, Jaime (org.). Pirandello: do teatro no teatro. São Paulo: Perspectiva, 2009.

REBUZZI, Solange. Leminski, guerreiro da linguagem: uma leitura das cartas-poemas de Paulo Leminski. Rio de Janeiro: 7 letras, 2003.

RETTAMOZO, Luiz Carlos. Fique doente, não ficção. Curitiba: Diário do Paraná, 1977.

RISÉRIO, Antonio. Oração aos moços. Diário do Paraná, Curitiba, Anexo, 10 jul. 1977a.

RISÉRIO, Antonio. Poesia concreta: por dentro e por fora. Diário do Paraná, Curitiba, Anexo, 12 abr. 1977b.

VIVEIROS DE CASTRO, Eduardo. Antropologia e imaginação da indisciplinaridade. Conferência proferida no IEAT-UFMG em 18 maio 2005. Belo Horizonte. Disponível em: http://www.ufmg.br/ieat/index.php?option=com_content\&task=view\& $\mathrm{id}=114 \&$ Itemid=193. Acesso em: 4 nov. 2011.

VIVEIROS DE CASTRO, Eduardo. A Super Estrutura. Entrevista concedida a Caio Liudvik. Folha de S. Paulo, São Paulo, Caderno Mais, 23 nov. 2008.

\section{NOTAS}

${ }^{1}$ Publicado entre 1976 e 1977, tinha à frente o poeta Paulo Leminski e o multiartista Luiz Carlos Rettamozo, e pretendia mobilizar artistas e intelectuais locais e de outras partes do Brasil na tentativa de agitar a cena cultural curitibana.

${ }^{2}$ Expressão criada por Ezra Pound para designar um processo de seleção e organização do repertório de saberes do passado considerados relevantes para o presente.

${ }^{3}$ De acordo com Araujo e Pereira (2016), trata-se de uma experiência do tempo na qual prevalece uma conduta atualizadora.

${ }^{4}$ Palavra grega que significa paixão, passividade, sofrimento, assujeitamento, sentimento, doença.

Artigo recebido em 13 de outubro de 2018.

Aprovado em 6 de junho de 2019. 